
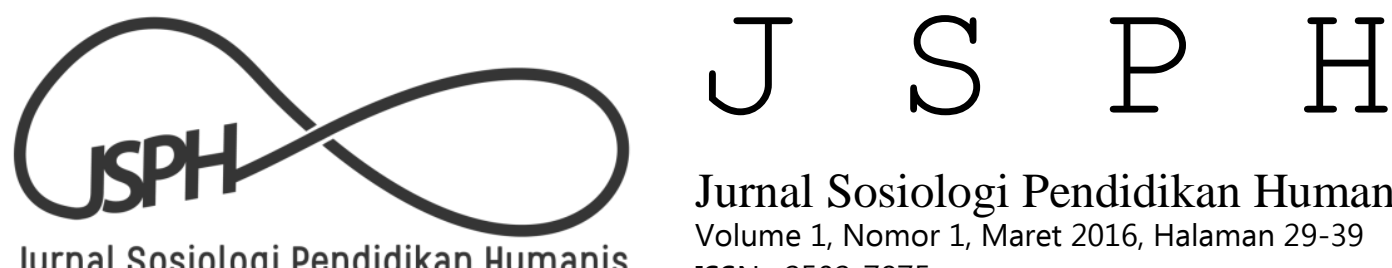

Jurnal Sosiologi Pendidikan Humanis

Volume 1, Nomor 1, Maret 2016, Halaman 29-39

ISSN : 2502-7875

\title{
TINJAUAN SOSIOLOGIS PERENCANAAN PEMBANGUNAN BERBASIS KAMUS E-MUSRENBANG
}

\section{Masrizal}

Program Studi Sosiologi FISIP Universitas Syiah Kuala Banda Aceh

\begin{abstract}
Abstrak
Tulisan ini menjelaskan bagaimana ruang partisipasi perempuan melalui Musrena (musyawarah rencana aksi perempuan) digerakkan kelompok perempuan pada akar rumput yang disebut organisasi Balee Inong yang ada di Banda Aceh. Terdapat 18 Balee Inong pada 90 gampong/desa. Pada tahapan ini penulis mendeskripsikan temuan tentang perencanaan pembangunan berbasis kamus eMusrenbang dengan pendekatan kerangka konsep pemberdayaan berspektif gender dengan pendekatan participatory rural appraisal. Teknik pengumpulan data dengan tinjauan kepustakaan, observasi, wawancara dan FGD. Hasil penelitian menunjukkan dalam aplikasi e-Musrenbang ini terdapat kamus usulan berisi jenis-jenis program kegiatan Satuan Kerja Perangkat Daerah (SKPD). Aplikasi ini dilengkapi WebGis.WebGis terkoneksi dengan Bappeda sehingga Gampong memiliki opsi memilih lokasi yang menjadi objek usulan pembangunan yang mereka usulkan. Per Gampong diberikan batasan pagu anggaran berdasar PIK (Pagu Indikatif Kecamatan) yang merupakan salah satu kebijakan Pemerintah Banda Aceh dalam proporsi anggaran untuk kecamatan dan gampong, dimana pada tahun 2015 Musrena diarahkan pada penjelesan kesiapan kelompok Balee Inong dalam mengkoneksikannya dengan SKPD terkait dengan masing-masing gampong mendapat pagu 10\% dari 200 juta rupiah/gampong dari budgeting data yang diperuntukkan melalui sumber dana APBD, sehingga warga bisa mengakses dan memahami secara online sampai dimana usulan desa mereka dapat diterima SKPD terkait.
\end{abstract}

Kata Kunci: perencanaan, partisipasi, perempuan, e-musrenbang

\section{SOCIOLOGICAL REVIEW OF DEVELOPMENT PLANNING BASED ON E- MUSRENBANG DICTIONARY}

Abstract

This paper describes how the participation of women through Musrena (consensus action plan female) driven group of women at the grass-roots organization called the women's centers in Banda.There are 18 women's centers in 90 village. At this stage, the authors describes on development planning based $e$-Musrenbang dictionary with the conceptual framework approach to gender empowerment with participatory rural appraisal approach. Data collection with a review of literature, observation, interviews and FGD. The results showed in the application of e-Musrenbang there are proposals dictionary contains the types of programs of activities of regional work units (SKPD). The application comes WebGis.WebGis connected with the Agency so that the Village has the option to choose the location that became the object of their proposed development proposal. Each Village given limit budget ceiling based PIK (Indicative Ceiling Sub-district) which is one of the policy of the Government in the proportional budget for the sub-district and village levels. Musrena directed for readiness group Balee Inong. Each village receive 10\% of the indicative ceiling of 200 million rupiah/ village of budgeting data designated by source of funds Banda Aceh, so that citizens can access it online through their village where proposals are acceptable.

Keywords: planning, partisipation,women, e-Musrenbang 


\section{LATAR BELAKANG}

Sistem perencanaan pembangunan dan penjaringan aspirasi masyarakat selama ini dilakukan melalui sistem Musyawarah Perencanaan dan Pembangunan (selanjutnya disingkat Musrenbang) yang dilakukan mulai dari tingkat gampong/desa hingga tingkat kabupaten/kota. Pelaksanaan dari satuan unit paling rendah di tingkat gampong masih berjalan top-down. Mekanisme perwakilan masyarakat biasanya lebih banyak diwakili oleh ketua atau anggota Tuha Peut. Sehingga terkesan lebih merupakan ajang sosialisasi pada masyarakat sekaligus sinkronisasi antara rencana kerja Satuan Kerja Pemerintah Aceh (SKPA) dengan Satuan Kerja Pemerintah Kabupaten/Kota (SKPK). Di samping itu, dalam hal waktu pelaksanaannya sering dikritik terlampau singkat sehingga masyarakat kurang memiliki kesempatan mengkritisi maupun mengklarifikasi usulannya, selain itu sebagian masyarakat juga seringkali datang tidak mempersiapkan diri sehingga tidak menguasai substansi dari program-program yang diusulkan.

Secara teknis, dalam pelaksanaan Musrenbang masih dilakukan secara maraton dan paralel. Mulai dari tingkat gampong/desa telah disusun jadwal yang dibuat oleh Bappeda Kota. Dalam satu hari dibagi gampong yaitu pagi dan siang hari. Masingmasing desa dan gampong mengadakan musyawarah di meunasah atau kantor balai pertemuan gampong dalam waktu 3-4 jam. Jika kita mengamati alur perencanaan daerah, dimana Musrenbang menjadi salah satu kegiatan yang harus dilalui, terlihat jelas bahwa perencanaan lebih bercorak tekno-kratik-formalistis dalam rangka menjaring aspirasi secara adiministratif. Rumusan yang dihasilkan lebih banyak bersifat pembangunan fisik seperti pembangunan pagar, renovasi kantor desa, perbaikan jalan, dan pembangunan gedung pertemuan dan sebagainya. Rumusan usulan telah diformalisasikan dalam bentuk isian form yang sudah disebarkan oleh Bappeda. Karena Musrenbang merupakan forum berjenjang, usulan-usulan yang disampaikan di tingkat gampong pun akan terus dibawa ke tingkat yang lebih tinggi sehingga disinilah persoalan akan muncul.

Misalnya, persoalan pertama,program yang sudah disepakati pada tingkat bawah (gampong/desa) belum tentu semuanya terakomodir ketika di aspirasikan ke forum ditingkat kecamatan hingga kabupaten/kota. Sehingga, banyak usulan-usulan tidak melihat pada kebutuhan masing-masing ditingkat gampong/desa, yang terjadi sebaliknya, usulan yang seharusnya sudah disampaikan pada tahun sebelumnya menjadi prioritas kembali, kerap menjadi pengulangan usulan tahun sebelumnya. Persoalan kedua, rendahnya keterlibatan/partisipasi perempuan di dalamnya, sehingga secara langsung ataupun tidak, banyak program atau kebijakan-kebijakan yang diterapkan oleh Pemerintah kabupaten/kota sering bermasalah terkait sensitivitas gender dan cenderung bias gender. Oleh karena itu, dilihat dari mekanisme pelaksanaannya, tingkat kehadiran perempuan yang minim, rumusan program yang dihasilkan tidak berkeadilan gender, sehingga dipandang perlu terbangunnya sebuah wadah yang sama yang dapat menampung seluruh persoalan dan kebutuhan perempuan, maka dirasa perlu diadakan Musrena.

Secara umum Musrena bertujuan untuk menciptakan perencanaan kota Banda Aceh berbasis keadilan gender dengan mengadaptasi sistem perencanaan bottom up 
dan top down. Sedangkan secara khusus adalah: (1) sebagai wadah komunikasi langsung bagi kaum perempuan di daerah sekaligus pembelajaran dalam merumuskan suatu rencana aksi pembangunan. Di sisi lain, menjadi ajang pembelajaran bagi kaum perempuan untuk ikut berpartisipasi aktif dalam meng-utarakan permasalahan serta kebutuhannya secara nyata dalam kegiatan musrenbang. (2) Sebagai salah satu dasar pertimbangan proporsi Anggaran Pendapatan dan Belanja Gampong (APBG atau Bantuan Gampong). (3) Sebagai upaya khusus sementara yang dilakukan pemkot untuk memastikan partisipasi perempuan dalam perencanaan, pelaksanaan, monitoring dan menikmati hasil pembangunan.

Manfaat umum musrena adalah dapat memperkuat kapasitas kaum perempuan di dalam proses perencanaan pembangunan, dan dapat memberikan masukan kepada pemerintah mengenai aspirasi-aspirasi kaum perempuan, mendengarkan dengan lebih jelas hal-hal apa yang menjadi aspirasi kaum perempuan yang bisa jadi belum terakomodir oleh kaum Adam, dan kemudian dapat diintegrasikan di dalam program kerja pemerintah. Sedangkan manfaat khu-sus adalah Pemerintah Kota Banda Aceh dapat mengetahui keluhan, permasalahan dan kebutuhan perempuan sehingga dapat di rumuskan solusi penangulangan dalam perencanaan pembangunan. Di masa kepemimpinan almarhum Mawardi Nurdin dan Illiza Sa'aduddin Djamal, Musrena (musyawarah rencana aksi perempuan) yang dijalankan berdasarkan Peraturan Walikota (Perwal No 52 tahun 2009) telah mendapatkan penghargaan secara nasional dalam bidang partisipasi perempuan dalam pembangunan. Selanjutnya Walikota membentuk organisasi perempuan tersebut dengan sebutan Balee Inong dengan diberi- kan SK yang dibuat oleh Kantor Pemberdayaan Perempuan Dan Keluarga Berencana (PPKB).

Balee Inong adalah sekumpulan indivi$\mathrm{du}$ perempuan yang saling bekerjasama dalam menyelesaikan persoalan pembangunan, baik dari tingkat gampong/desa hingga ketingkat kecamatan sampai dengan kabupaten/kota. Organisasi ini hanya ada di Kota Banda Aceh, dan tidak ada diwilayah lain diluar Kota Banda Aceh, dengan jumlah organisasi sampai sekarang Bale Inong berjumlah BI sekarang 18 .

Sebagaimana diketahui pada tahun 2015 ini Bappeda Kota Banda Aceh telah merancang Kamus e-Musrenbang yang di dalam program tersebut pagu indikatifnya dari budgeting 200 Juta rupiah pergampong, dimana $10 \%$ diperuntukkan untuk kegiatan organisasi Balee Inong yang berada pada 90 gampong dan $90 \%$ lainnya untuk kegiatan gampong yang dikelola oleh aparatur gampong. Selama ini organisasi BI ini berada ditingkat kemukiman, jadi sebagai sebuah organisasi yang baru mendapat perhatian serius dari Pemerintah Kota Banda Aceh maka sangat diperlukan pengetahuan tentang bagaimana merancang program kegiatan yang mendukung capaian MDGs (Millenium Development Goals). Untuk itu penulis ingin melihat kekuatan dan kelemahan yang dipraktikkan oleh organisasi Bale inong dalam partisipasinya melalui Musrena sebagai sebuah afirmatif Musrenbang yang belum berpihak pada kebutuhan perempuan.

Berikutnya adalah pemimpin yang memiliki kapasitas diri bersaing dengan pemimpin global. Mereka mampu membawa bangsa ini berdaya tawar tinggi, sehingga mampu disegani oleh bangsa lain. Tidak seperti yang kita amatai sekarang, Negara sering kali dintervensi oleh bangsa asing. 
Negara masih "diinjak-diinjak", wilayah kedaulatan masih di tabrak, dan kekayaan milik bangsa Indonesia masih dicuri dan dijajah. Anehnya pemimpin kita masih tenang-tenang saja. Kita butuh pemimpin yang tegas terhadap bangsa lain yang berusaha mengganggu keutuhan bangsa ini. Selain itu, Indonesia butuh pemimpin yang mampu mengangkat martabat bangsa ini, bukan secara citra, melainkan secara fakta.

Terakhir, menurutnya Indonesia butuh pemimpin yang mau hidup sederhana, pemimpin yang sudah selesai dengan dirinya sendiri, punya integritas tinggi, juga mampu menjadi contoh bagi yang lain. Bangsa ini butuh pemimpin yang demikian, karena Indonesia sedang mengalami krisis nilai, krisis moral, dan krisis contoh pemimpin yang baik ${ }^{1}$.

\section{METODE PENELITIAN}

Dalam mengkaji partisipasi perem-puan yang tergabung dalam organisasi Balee Inong dalam Musrena pendekatan yang digunakan melalui metode Kualitatif dengan teknik pengumpulan datanya: tinjauan kepustakaan, observasi, wawancara, dan FGD (focus group discussion).

\section{Kerangka Teoritik}

Dalam kajian teori ini penulis akan menggambarkan beberapa bentuk model kerangka analisis teori gender yang dikembangkan oleh beberapa ahli yang digunakan untuk melihat model konsep pelaksanaan Musrena melalui kekuatan organisasi kelompok perempuan pada level akar rumput yang disebut dengan Balee Inong di Kota Banda Aceh antara lain:

1 Hasil wawancara dengan Moh. Husen, mahasiswa matematika UWKS, tanggal 30 September 2014

\section{Harvard Framework}

Kerangka analisis gender Harvard lebih concern dengan membuat pembagian kerja gender (division of labour), peran dalam pengambilan keputusan, tingkat kontrol atas sumberdaya yang kelihatan. Tiga data set utama yang diperlukan:Siapa melakukan apa, kapan, di mana, dan berapa banyak alokasi waktu yang diperlukan? Hal ini dikenal sebagai "profil aktifitas".Siapa yang memiliki akses dan kontrol (seperti pembuat an kebijakan) atas sumber daya tertentu? Hal ini kerap dikenal dengan "profil akses dan kontrol”. Dan terakhir siapa yang memiliki akses dan kontrol atas "benefit" seperti produksi pangan, uang dan sebagainya. Faktor yang mempengaruhi perbedaan dalam pembagian kerja berbasis gender, serta akses dan kontrol yang ada pada "profil aktifitas" dan "profil akses dan kontrol". Tujuan dari alat analisis ini adalah membedah alokasi sumberdaya ekonomis terhadap laki-laki dan perempuan, membantu perencana proyek untuk lebih efisien dan meningkatan produktifitas secara keseluruhan.

\section{Kerangka Moser}

Kerangka Moser atau sering disebut dengan The Gender Roles Framework, Secara singkat, kerangka ini menawarkan pembedaan antara kebutuhan praktis dan strategis dalam perencanaan pemberdayaan komunitas dan berfokus pada beban kerja perempuan. Uniknya, ia tidak berfokus pada kelembagaan tertentu tetapi lebih berfokus pada rumah tangga.Tiga konsep utama dari kerangka ini adalah: pertama,peran lipat tiga (triple roles) perempuan pada tiga aras: kerja reproduksi, kerja produktif dan kerja komunitas. Ini berguna untuk pemetaan pembagian kerja gender dan alokasi kerja. Kedua, berupaya untuk membedakan antara kebutuhan yang bersifat praktis dan strategis 
bagi perempuan dan laki-laki. Kebutuhan strategis berelasi dengan kebutuhan transformasi status dan posisi perempuan (seperti sub-ordinasi). Sedangkan ketiga, pendekatan analisis kebijakan - dari fokus pada kesejahteraan (welfare), Kesamaan (equity), anti kemiskinan, efisiensi dan pemberdayaan.

\section{Kerangka Konsep}

\section{Konsep Longwe tentang kerangka kerja.}

"Pemberdayaan" atau sering diistilahkan dengan Longwe Framework. Kerangka Longwe berfokus langsung pada penciptaan situasi/pengkondisian dimana masalah kesenjangan, diskriminasi dan subordinasi diselesaikan. Longwe menciptakan jalan untuk mencapai tingkat pemberdayaan dan kesederajatan (equality) di mana ditunjukan bahwa pemenuhan kebutuhan dasar-praktis perempuan tidak pernah sama dengan, pemberdayaan maupun sederajat (equal). Pengambilan keputusan (kontrol) merupakan puncak dari pemberdayaan dan kesederajatan (equality).

\section{Kerangka AnalisisRelasi Sosial Naela Kabeer}

Kerangka ini didasarkan pada ide bahwa tujuan pembangunan adalah pada kesejahteraan manusia (human well-being), yang terdiri atas survival, security dan otonomi. Produksi dilihat bukan hanya relasinya terhadap pasar, tetapi juga reproduksi tenaga kerja, kegiatan subsistent, dan kepedulian lingkungan hidup. Menganalisis ketimpangan gender yang ada di dalam distribusi sumber daya, tanggung jawab dan kekuasaan. Menganalisis relasi antara orang, relasi mereka dengan sumber daya, aktifitas dan bagaimana posisi mereka melalui lensa kelembagaan, dan menekankan kesejahteraan manusia (human well being) sebagai tujuan utama dalam pembangunan.

\section{Konsep Web Geographic Information System (WebGIS)}

Menurut Prahasta (2007), WebGIS adalah aplikasi GIS atau pemetaan digital yang memanfaatkan jaringan internet sebagai media komunikasi yang berfungsi untuk mendistribusikan,mempublikasikan, mengintegrasikan, mengkomunikasikan sekaligus menyediakan informasi dalam bentuk teks, peta dijital serta menjalankan fungsi-fungsi analisis dan query yang terkait dengan GIS melalui jaringan internet. Sedangkan menurut Setiawan dan Rabbasa, penggunaan data spasial dirasakan semakin diperlukan untuk berbagai keperluan seperti penelitian, pengembangan dan perencanaan wilayah, serta manajemen sumber daya alam.Pengguna data spasial merasakan minimnya informasi mengenai keberadaan dan ketersediaan data spasial yang dibutuhkan. Penyebaran (diseminasi) data spasial yang selama ini dilakukan dengan menggunakan media yang telah ada yang meliputi media cetak (peta), cd-rom, dan media lainnya yang dirasakan kurang mencukupi kebutuhan pengguna. Pengguna diharuskan datang dan melihat langsung data tersebut pada tempatnya (data provider). Hal ini mengurangi mobilitas dan kecepatan dalam memperoleh informasi mengenai data tersebut. Karena itu dirasakan perlu adanya WebGIS.

Arsitektur aplikasi pemetaan di web dibagi menjadi dua pendekatan sebagai berikut :

\section{a) Pendekatan Thin Server}

Pendekatan ini memfokuskan diri pada sisi server. Hampir semua proses dan analisis data dilakukan berdasarkan request di 
sisi server. Data hasil pemrosesan kemudian dikirim ke client dalam format standar.

b) Pendekatan Thick Client

Pada pendekatan ini, pemrosesan data dilakukan disisi client menggunakan beberapa teknologi (Nuryadin, 2005). Secara umum pengembangan dan implementasi WebGIS akan menunjang penyebaran informasi data spatial. Sehingga orang awam pun akan dapat memiliki akses terhadap data dan hasil analisis GIS.

\section{HASIL DAN PEMBAHASAN Musrena sebagai Afirmatif dari Musrenbang}

Berangkat dari persoalan formalisme musrenbang dengan berbagai masalahnya, kemudian hadir sebuah ide dari wakil walikota Banda Aceh saat itu, dan sekarang sudah menjadi Walikota menggantikan Alm. Mawardi Nurdin, untuk membuat wadah yang dapat menampung aspirasi kaum perempuan dalam perencanaan pembangunan kota, yaitu musrena. Forum ini dibentuk oleh Pemerintah Kota, atas tiga inisiator utama yaitu Wakil Walikota terpilih, Illiza Sa'aduddin Djamal; Fahmiwati dan ibuk Suzan dari GTZ-SLGSR, yang dalam pelaksanaan awal juga didukung oleh berbagai aktivis lainseperti Soraya Kamaruzzaman, Ir Badrunnisa, Kusmawati Hatta, Ria Fitri, Tasmiati sebagai fasilitator. Yang seterusnya fasili-tator tersebut dilakukan oleh Kusmawati Hatta, Ridwan Ibrahim. Forum ini dimulai sejak tahun 2007 dilaksanakan di tingkat kecamatan yang dibagi dalam tiga regional.

Secara umum musrena bertujuan un-tuk mencipatakan Perencanaan Kota Banda Aceh Berbasis Keadilan Gender dengan mengadaptasi sistem perencanaan bottom up dan top down. Sedangkan secara khusus adalah: (1) sebagai wadah komunikasi lang- sung bagi kaum perempuan di daerah sekaligus pembelajaran dalam merumuskan suatu rencana aksi pembangunan. Di sisi lain, menjadi ajang pembelajaran bagi kaum perempuan untuk ikut berpartisipasi aktif dalam mengutarakan permasalahan serta kebutuhannya secara nyata dalam kegiatan Musrenbang. (2) Sebagai salah satu dasar pertimbangan proporsi Anggaran Pendapatan dan Belanja Gampong (APBG atau Bantuan Gampong). (3) Sebagai upaya khusus sementara yang dilakukan pemerintah kota untuk memastikan partisipasi perempuan dalam perencanaan, pelaksanaan, monitoring dan menikmati hasil pembangunan.

Manfaat umum musrena adalahdapat memperkuat kapasitas kaum perempuan di dalam proses perencanaan pembangunan, dandapat memberikan masukan kepada pemerintah mengenai aspirasi-aspirasi kaum perempuan, mendengarkan dengan lebih jelas hal-hal apa yang menjadi aspirasi kaum perempuan, dan kemudian dapat diintegrasikan didalam program kerja pemerintah. Sedangkan manfaat khusus adalah Pemerintah Kota Banda Aceh dapat mengetahui keluhan, permasalahan dan kebutuhan perempuan sehingga dapat di rumuskan solusi penanggulangan dalam perencanaan pembangunan.

Untuk memperkuat keberadaannya dari sisi legal-formal, kemudian dimunculkan sejumlah regulasi di tingkat lokal, yakni: Perwal Musrena No 52 tahun 2009, Qanun Kota Berkeadilan Gender; Posisi Perempuan yang Menduduki Jabatan Strategis di Pemerintahan; Rencana Pemerintah Jangka Menengah (2007-2012); Renstra, Renja, KUA/PPAS.

Sedangkan regulasi nasional yang dijadikan sandaran dan juga untuk menjaga sustainibilitas khususnya terkait dengan 
hambatan-hambatan adininistratif merujuk regulasi pembangunan partisipatif, utamanya adalah: UU RI No. 25 Th. 2004 (UU 25/2004) tentang Sistem Perencanaan Pembangunan Nasional (SPPN); UU RI No. 32 Th. 2004 tentang Pemerintahan Daerah, dan;UU RI No. 33 Th. 2004 tentang Perimbangan Keuangan Antara Pemerintah Pusat dan Daerah;UU RI No. 7 Th. 1984 tentang Pengesahan Konvensi Mengenai Pengha-pusan Segala Bentuk Diskriininasi Terhadap Perempuan (Lembaran Negara Tahun 1984 Nomor 29 Tambahan Lembaran Negara 3277);UU RI No 39 tahun 1999 tentang Hak Azasi Manusia; UU RI No 23 tahun 2004 tentang Penghapusan Kekerasan Dalam rumah tangga;UU RI No. 25 Tahun 2000 tentang Propenas khususnya Bab VIII tentang kedudukan dan kualitas hidup perempuan; UU RI No. 11 tahun 2006 tentang Pemerintahan Aceh, terutama pada: pasal 75 tentang keterwakilan perempuan dan Partai politik lokal, Pasal 138 tentang perempuan dan pembentukan MPU,pasal 154 tentang perempuan dan perekonomian, pasal 215 tentang perempuan dan pendidikan, pasal 231 tentang perempuan dan anak dan HAM. Pasal 226 tentang perem-puan dan kesehatan dan psikososial; kemudian Instruksi Presiden RI No. 9 Tahun. 2000 tentang Pengarusutamaan Gender dalam Pembangunan Nasional;PP No. 19 Tahun 2001 mengenai pengarusutamaan gender; Surat Edaran Bersama (SEB) Menteri Negara Perencanaan Pembangunan Nasional/ Kepala Bappenas dan Menteri Dalam Negeri No.0008/M. PPN/01/2007 dan 050/264A/SJ tentang Petunjuk Teknis Penvelenggaraan MUSRENBANG Tahun 2007. SEB ini merupakan peraturan transisi sambil menunggu keluamya peraturan pemerintah (PP) sebagai aturan pelaksanaan UU
SPPN;Konvensi Mengenai Hak-hak Politik Perempuan (Convention on the Political Rights of Women, New York 31 March 1953), Indo-nesia meratifikasi konvensi tanggal 16 Desember 1998); Protokol Obsional terhadap Konvensi Penghapusan Segala Bentuk Diskriminasi Terhadap Perempuan;PP No. 8 Tahun 2008 tentang Tahapan dan Tata Cara Penyusunan, Pengendalian, Pe-laksanaan Evaluasi Pembangunan Daerah.

\section{Keunggulan kamus e-Musrenbang bagi warga kota Aceh}

Keunggulan aplikasi Kamus e-Musrenbang adalah masyarakat dapat mengikuti sejauh mana sudah usulan program pembangunan mereka diakomodir oleh Pemerintah kota Banda Aceh, melalui SKPD (satuan kerja pemerintah daerah) terkait. Dalam aplikasi ini terdapat kamus usulan berisi jenis-jenis program kegiatan SKPD yang sudah memiliki harga satuan, sehingga operator gampong tinggal memilih dan memasukkan volume yang dibutuhkan. Aplikasi ini juga dilengkapi dengan WebGis yang dikoneksikan dengan WebGis Bappeda sehingga gampong memiliki opsi memilih lokasi yang menjadi objek usulan pemba-ngunan yang mereka usulkan."Per gampong/desa diberikan batasan pagu anggaran berda-sarkan PIK (Pagu Indikatif Kecamatan) yang merupakan salah-satu kebijakan Pemerintah Banda Aceh dalam proporsional anggaran untuk tingkat kecamatan dan gampong/desa. Dengan hadirnya aplikasi ini, diharapkan kualitas perencanaan yang melibatkan masyarakat secara langsung dapat terlaksana dengan baik, sehingga cita-cita kota Banda Aceh menjadi Cyber City lebih cepat terwujud.

Hal lain dari kajian ini bisa kita merujuk pada konsep pemberdayaan yang 
dikembangkan melalui pendekatan Participatory Rural Appraisal (PRA), atau kajian pemberdayaan yang dikembangkan oleh Longwe berfokus langsung pada penciptaan situasi/pengkondisian di mana masalah kesenjangan, diskriminasi dan subordinasi diselesaikan. Longwe menciptakan jalan untuk mencapai tingkat pemberdayaan dan kesederajatan (equality) di mana ditunjukan bahwa pemenuhan kebutuhan dasar-praktis perempuan tidak pernah sama dengan, pemberdayaan maupun sederajat (equal). Pengambilan keputusan (kontrol) merupakan puncak dari pemberdayaan dan kesederajatan (equality).

Musrenbang sebagai suatu kegiatan tahunan yang diamanatkan oleh UndangUndang, merupakan ajang bertemunya warga gampong untuk mendiskusikan permasalahan mereka dan memutuskan prioritas pembangunan jangka pendek. Musrenbang merupakan bentuk partisipasi masyarakat dalam pembangunan secara bottom-up dengan memastikan pembangunan sesuai dengan kebutuhan. Dalam rangka mensosialisasikan sistem baru musrenbang secara online, Bappeda mengundang para camat dan geuchik/kepala desa dalam kawasan Kota Banda Aceh untuk memperkenalkan aplikasi electronic Musrenbang.

Selanjutnya pada tahun 2015, kelompok perempuan yang tergabung dalam organisasi Balee Inong mendapatkan pengetahuan tentang sistem operasional e-musrenbang karena dari pagu Indikatif Gampong yang ada di Kota Banda Aceh, anggaran 10\% dari gampong dikelola oleh kelompok perempuan, dimana contohnya pada anggaran tahun 2016 mendatang, dari total Anggaran 200 juta rupiah Pergampong/desa maka $10 \%$ nya diperuntukkan bagi program kegiatan yang berhubungan dengan perempuan. Dimana di Banda Aceh ada 90 Gampong jadi ada sekitar, 1,8 Milyar Rupiah akan dikelola oleh Kelom-pok perempuan yang tergabung dalam organisasi Balee Inong tersebut. Selama ini organisasi Balee Inong ini didampingi oleh Badan Pemberdayaan Perempuan dan Keluarga Berencana Kota dan lembaga Women's Development Centre Kota Banda Aceh.

\section{Realisasi Musrena terhadap Kebijakan Pembangunan berperspektif Gender.}

Pascaada musrena sebagai forum aspirasi bagi perempuan Kota Banda Aceh dalam pembangunan, telah banyak manfaat yang dirasakan, baik dari sektor ekonomi, pendidikan, budaya, agama, politik dan sektor sosial lainnya. Begitu juga dengan instansi terkait, program kegiatan yang direalisasikan lebih mengarah kepada kebutuhan masyarakat, bukan hanya sekedar program asal jaadi yang tanpa memiliki dukungan penuh dari masyarakat, terutama kelompok perempuan sebagai objek penerima manfaat bantuan.

Sejak musrena direalisasikan sejak tahun 2007, program yang mengarah kepada kepentingan perempuan terealisasikan sedikit demi sedikit dengan tidak lagi melihat kepentingan yang diimplementasikan mengarah kepada kepentingan yang bersifat sementara, hanya untuk perempuan semata tetapi mengarah kepada kepentingan gender (laki-laki dan perempuan). Misalnya dalam forum tersebut, adanya usulan yang kemudian terealisasi seperti, penambahan modal usaha dana bergulir, penerangan lampu jalan gampong/desa, pelatihan tajhiz mayat, dan kagiatan sosial lainnya. Selan-jutnya pada tahun 2015, pagu indikatif gampong diperuntukkan untuk perempuan $10 \%$ dari APBK. Sehingga banyak program yang diusulkan membantu pembangunan kota 
yang menjawab visi dan misi Kota Banda Aceh sejak 2007-2012, hingga 2012-2017. Namun berjalannya program kegiatan yang diprakarsai oleh kelompok perempuan ini tidak terlepas dari sikap kepemimpinan yang dinampakkan oleh Illiza Sa'aduddin Djamal, sebagai seorang perempuan yang lahir dari kader partai politik, dan juga organisasi Perempuan yang ada di kota Banda Aceh, baik organisasi dilevel desa (Balee Inong) Juga LSM di level kota, seperti WDC, KKTGA, Flower, RPUK, Annisa Centre, MISPI, Balai Syura, LBH, dan LSM lainnnya yang berada di Ibukota Provinsi Aceh.

Selanjutnya Peranan dan Fungsi Organisasi Masyarakat Sipil di Kota Banda Aceh, Peranan dan tanggung jawab organisasi masyarakat sipil dalam Musrenbang dan Musrenadapat dijelaskan:

1. Adanya Pengembangan koalisi strategis dan jaringan yang efektif untuk mempengaruhi pengambilan keputusan dalam proses perencanaan dan penganggaran di daerah untuk menerapkan pengnggaran partisipatif;

2. Disamping sebagai peserta mereka juga berperan menjadi fasilitator Musrenbang;

3. Memberikan advokasi, pelatihan, pendampingan, penelitian, dan analisis anggaran;

4. Menyediakan dan meningkatkan akses masyarakat pada informasi perencanaan dan penganggaran agar mereka lebih peduli dan aktif berkontribusi dalam prosesnya;

5. Menciptakan forum publik untuk mendorong pembahasan APBD sebelum APBD disetujui dan disahkan;

6. Melakukan kampanye untuk mendorong transparansi anggaran;
7. Memantau dan mengevaluasi anggaran dan kinerja pelayanan publik;

8. Membantu DPRK untuk melakukan tinjauan (review) dan penilaian terhadap dampak anggaran yang diusulkan pemerintah daerah, terutama dampak anggaran bagi usaha pengentasan kemiskinan dan penerapan standar pelayanan minimal;

9. Bekerjasama dengan media cetak ataupun elektronik untuk memastikan tujuan-tujuan perencanaan dan penganggaran partisipatif, proses, dan hasilhasilnya dipublikasikan.

Begitu juga dengan peranan dan fungsi DPRD Kota Banda Aceh, untuk menguatkan keterlibatan DPRD dalam Musrenbang dan Musrena khususnya dan semua tahapan proses perencanaan pada umumnya. Di samping jadwal waktu reses DPRD perlu disinkronisasikan dengan jadwal waktu Musrenbang dan kalender perenca naan dan penganggaran daerah. Dengan demikian DPRD dapat berkontribusi aktif dan efektif dalam Musrenbang pada saat kegiatan tersebut dilaksanakan. Dimana pada saat Musrena berlangsung DPRK men dengarkan paparan masing-masing kelom pok organi-sasi Perempuan Kota Banda Aceh yang tergabung dalam organi sasi Balee Inong, dan titik tekan yang paling ber pengaruh terhadap realiasasi program Musrena adalah anggota legislatif yang ter pilih dari Dapil (daerah pemilihan) tertentu mesti hadir, dan berkontribusi dalam forum tersebut. Peranan dan fungsi DPRK yang diperkuat dalam forum Musrena sebagai berikut:

1. Adanya keterlibatan aktif dari komisi, komite DPRD yang relevan dalam diskusi, peninjauan, dan evaluasi usulan masyarakat dalam Musrena dan Musrenbang; 
2. Pemahaman terhadap kebutuhan danaspirasi masyarakat disuarakan dalam Musrenbang dan memberikan masukan atas prioritas program berdasarkan prioritas masayarakat;

3. Terdapatnya konsistensi dan keseimbangan antara program dan anggaran tahunan daerah dengan prioritas nasional dan provinsi dan antara prioritas sektoral dengan alokasi anggaran;

4. Musrenbang menerapkan standar konsultasi publik yang sesuai; mencermati kebutuhan pengembangan regulasi untuk dimasukkan dalam program Renja DPRK mendukung program dan kegiatan yang diprioritaskan di Musrena pada pengusulan Musrenbang.

Advokasi anggaran berkeadilan gender mulai diterapkan sejak 2001 oleh beberapa LSM anggota forum Gender Budget Analysis yang bekerja pada tingkat nasional dengan jaringan di daerah dan anggota forum yang bekerja di daerah. Pada level nasional, forum tersebut melakukan advokasi gender budget dengan mendesak Majelis Permusyawaratan Rakyat (MPR) agar mengalokasikan anggaran sebesar 30 persen untuk sektor pendidikan, kesehatan 15 persen, dan anggaran pemberdayaan perempuan 5 persen dari APBN (Ketetapan MPR Nomor 6 Tahun 2002). Untuk di Banda Aceh dikuatkan lagi dengan lahirnya Perwal Musrena Nomor 52 tahun 2008 yang meng-haruskan 5\% dari Alokasi Anggaran pada SKPD diarahkan pada realiasi program yang berkeadilan gender. Berdasarkan dari berbagai kekuatan hukum tersebut sehingga kegiatan Musrena di Kota Banda Aceh berjalan dengan baik dan akan diberhentikan ketika Musrenbang sudah mengakomodir partisipasi penuh perempuan dalam musrenbang, hingga tahun kesembilan musrena masih dilihat ada kekurangan, untuk itu musrena yang berada dibawah kendali Bappeda Kota Banda Aceh terus berbenah untuk perbaikan musrena selanjutnya dengan selalu menjalin koordinasi dengan pihak terkait.

\section{KESIMPULAN}

Sebagai bentuk afirmatif Musrenbang dari pemerintah dalam rangka peningkatan partisipasi aksi perempuan dalam pembangunan, dibentuknya Forum Musrena yang telah dilakukan terus menerus secara berkesinambungan selama 9 tahun, sejak 20072015, di Kota Banda Aceh, dengan mekanisme pelaksanaan penjaringan informasi dan program kegiatan sejak dari Pra Mus rena yang dirancang dari Desa/gam-pong, hingga kelevel Kecamatan, sampai dengan masuk kedalam realisasi Musren-bang ditingkat Kota, sampai sekarang terus di sempurnakan sesuai situasi dan kondisi. Dan hasil setiap tahunnya juga sudah ada yang diintergrasikan ke dalam program SKPK walaupun tidak meningkat secara signifikan. Oleh karena itu, maka sampai saat ini Musrena masih diperlukan untuk terus menjadi wadah pembelajaran bagi perem puan dalam mengeluarkan aspirasi dan inspi rasinya serta membantu perenca naan pembangunan kota yang partisipatif gender ke depan. Selain itu, pelaksanaan Musrena ini, sudah mulai dikenal dan dipelajari oleh berbagai pihak yang berke pentingan dalam rangka pengem-bangan, penyempurnaan dan program replikasi untuk melakukan sistem peren-canaan pem bangunan yang partisi patif. Dan bahkan organisasi WDC Banda Aceh bekerjasama denganPemerin-tah Kota Banda Aceh dengan dukungan dana dari Ford Foun dation telah melakukan sosialisasi program musrena melalui workshop ke Kabupaten/ kota Lainnya di 
Aceh seperti Aceh Selatan, Aceh Singkil, Kota Subulus-salam, Pidie Jaya, Aceh Besar dan Sabang. Dan dari hasil Sosialisasi tersebut didapatkan bahwa hampir semua kabupaten/kota tersebut menjadikan Musrena sebagai sebah contoh yang baik (best practice) dalam merealisasikan program yang berkeadilan gender didaerah masing-masing, dengan nama yang berbedabeda, ada yang disebut dengan Tim Vokal Poin Gender atau nama lainnya sesuai dengan kesepakatan masing-masing daerah. Dan bahkan pemerintah Kota Banda Aceh dengan adanya Musrena ini telah mendapatkan Inovasi Goverment Awards dari Kementerian tahun 2012.

\section{DAFTAR PUSTAKA}

Azhar,Arsyad.(1996).Media Pembelajaran Raja Grafindo Persada, Jakarta

Hurairah, Abu. (2006). Dinamika Kelompok (konsep dan Aplikasi), Refika Aditama, Bandung

Masrizal dkk. (2012). Analisis' Pengembangan Usaha Ekonomi Perempuan di Kota Banda Aceh, WDC, Ford Foundation- Penerbit Samudra Biru, Yogyakarta.

Masrizal dkk. (2012).Modul Musrena, WDC- Ford Foundation- Pemko Kota Banda Aceh
Masrizal dkk. (2015).Modul Pemberdayaan Perempuan (Sebuah Analisa Bale Inong dan Relasi Sosial)WDC- Ford Foundation- Pemko Kota Banda Aceh

Umar, Nasaruddin dkk. (2003)Pemberdayaan Perempuan Melalui Pemahaman Agama, PSG IAIN Sunan Ampel Surabaya

Onny S. Prijono. (1996).Pemberdayaan Masyarakat (Konsep, Kebijakan dan Implementasi), CSIS, Jakarta

\section{Website:}

http://www.bandaacehkota.go.id/berita965Dengan_eMusrenbang,_Masyarakat_Lebih _Terlibat_Dalam_Pembangunan.html\#.VeO piyuUqKE

http://www.bappedabandaacehkota.go.id/ strategi/musrena.

https://trezegulum17.wordpress.com/2013/ 01/07/musyawarah-perencanaan-

pembangunan-musrenbang/

http://kalyanamitra.or.id/eventsdetail.php? $i d=0 \& i d d a t a=1$

http://cgi.fisipol.ugm.ac.id 